\title{
Active Net Model by Multiple Nets Methods
}

\author{
Noboru Yabuki Non-member (Tsuyama National College of Technology, yabuki@tsuyama-ct.ac.jp) \\ Yasuaki Sumi Non-member (Tottori University of Environmental Studies, sumi@kankyo-u.ac.jp) \\ Fukuya Namba Non-member (Tottori University of Environmental Studies, m-namba@kankyo-u.ac.jp) \\ Takao Tsukutani Member (Matsue National College of Technology, tsukutani@matsue-ct.ac.jp)
}

Keywords: active net model, image processing, region detection, multiple nets

\section{Introduction}

In this paper, we propose a new method using multiple nets for Active Net model. Active Net ${ }^{(1)}$ is an expanded twodimensional version of the Snakes model. It has the ability to take image information inside a model, unlike Snakes which only uses contour, so it has an advantage in detecting a target. We propose the method of assuming that the image was divided into $\mathrm{n}$ parts and applying net to each divided image. The proposed method uses many nets.

\section{Active Net}

Active Net is a lattice network model which is based on minimizing an energy to extract the region of a target object. The structure of the net model consists of lattice points, linked with their 4-neighborhood nodes. Energy functions consist of two types, such as the internal strain energy of the net $E_{\text {int }}$, the image energy of the target image $E_{\text {image. }}$ The total energy $E_{n e t}$ of the net is written as a linear combination of above energy functions Minimizing the total energy function gives rise to Euler equations. The initial shape of a net is shown in Fig. 1 (a).

\section{Proposal Multiple Nets Methods}

An original image and a target currently used in simulations of this paper are shown in Fig. 1. The intensity of target region and background are 100 and 255 respectively. In Active Net, layers and sectors are 10 and 40 respectively. Layers are separate concentric squares in active net. Sectors are subdivision of the layers to smaller parts. A simulation is shown in Fig. 1 using the conventional method. The result is shown in Fig. 1(b). The net in Fig. 1(b) couldn' t detect the target. In this case, only one target can be used by one net. If there are many targets, it is necessary using many nets to repeat the same operation. The complex processing will be necessary.

Then, new method using multiple nets is proposed. That is, we have the assumption that the image was divided into $\mathrm{n}$ parts and applying nets to each divided image. This is referred to as the multiple nets methods. For example, the case

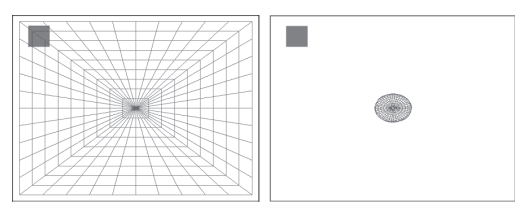

$\begin{array}{ll}\text { (a) First step } & \text { (b) Final step }\end{array}$

Fig. 1. Simulation result with conventional method

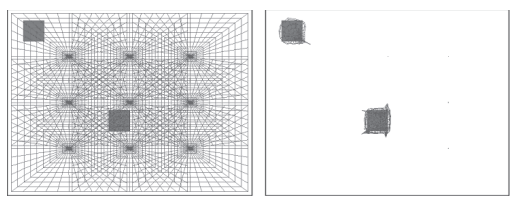

$\begin{array}{ll}\text { (a) First step } & \text { (b) Final step }\end{array}$

Fig. 2. Simulation result with proposed method, $\mathrm{n}=9$

of $n=9$ is shown in Fig. 2. In Fig. 2, the used image has two targets, and the simulation is done using proposed method. Fig. 2(a) shows initial nets and two targets. Fig. 2(b) is final result. New nets can detect two targets. The upper left target can be detected by the upper left net and the central target can be detected by the nets of the left middle. The other nets are contracted to the central point of each initial net without detecting target.

\section{Conclusion}

In this paper, a new method using multiple nets was proposed for Active Net model. Simulation results were obtained by applying proposed method to images. Since the size of a net became small, processing time to one net can be shortened. It means that the target detection performance had improved.

\section{References}

(1) K. Sakaue, and K. Yamamoto: "Active Net Model and Its Application to Region Extraction", JITE of Japan, Vol.45, No.10, pp.1155-1163 (1991) 


\title{
動的なネットモデルのマルチネット方式化
}

\author{
非会員 薮木 登* 非会員 鷲見 育亮** \\ 非会員 難波 福弥 ${ }^{* *}$ 正 員 築谷 隆雄 $* * *$
}

\author{
Active Net Model by Multiple Nets Methods \\ Noboru Yabuki*, Non-member, Yasuaki Sumi**, Non-member, Fukuya Namba**, Non-member, \\ Takao Tsukutani***, Member
}

In this paper, we propose a new method for Active Net model. Active Net is a lattice network model that is based on minimizing an energy to extract the region of a target object. In a conventional method, only one target is used by one net. Therefore, assuming that the image can be divided into some parts, the proposed method uses many nets and applies them to each divided image. Some simulation results are presented obtained by applying proposed method to images. In the proposed method, since the size of a net became small, processing time to one net can be shortened. Furthermore, since the distance between lattice points is short in initial net, the target at the end of an image became detectable. That is, it means that the target detection performance has improved.

キーワード：動的ネットモデル, アクティブネット, 画像処理, 領域検出, マルチネット

Keywords: active net model, image processing, region detection, multiple net

\section{1. まえがき}

本論文は，動的なネットモデル (Active Net) ${ }^{(1)}$ の画像 への適用において，画像を分割するのと同じ効果を持つよ うに，複数の Active Netを適用する方法の検討を行った 結果について述べている。ここで，複数のネットを配置す ることは，見掛け上，画像を分割し，ネットを適用するよ うに見えるので，この配置領域をネット適応領域（=分割 領域と以下呼ぶ）とする。

画像認識を行う過程で必要となる処理に，対象物体の検 出と形状抽出がある。その実現をエネルギー最適化問題と して捉えた変形可能なモデルを使う方法がある。一般的に

* 津山工業高等専門学校 情報工学科

T 708-8509 岡山県津山市沼 624-1

Department of Computer and Information Engineering, Tsuyama National College of Technology

624-1 Numa, Tsuyama-shi, Okayama 708-8509

** 鳥取環境大学 情報システム学科

厂 689-1111 鳥取県鳥取市若葉台北 1-1-1

Department of Information and System, Tottori University of Environmental Studies

1-1-1 Wakabadai-kita, Tottori-shi, Tottori 689-1111

*** 松江工業高等専門学校 電気工学科

干 690-8518 島根県松江市西生馬町 14-4

Department of Electrical Engineering, Matsue National College of Technology

14-4 Nishi-ikomacyou, Matsue-shi, Shimane, 690-8518
最適化問題に基づく形状抽出手法は, 雑音に強く, 安定なア ルゴリズムの動作が保証されているという利点がある ${ }^{(2)}$ 。 Snakes ${ }^{(3)}$ は，そのアプローチの代表例である。

Snakesによる方式は，エッジ情報にモデルの滑らかさな どの制約条件を付加することによって形状抽出の安定化を 図った動的な輪郭モデルである。しかしながら，エッジは 対象だけではなく, 他の領域にも存在するため, Snakesの 初期座標を前処理で抽出したい領域近くに設定しておく必 要がある。さらに, Snakes は対象領域周辺の不適切なエッ ジにより正確には領域を捕捉することができない場合があ る。これらの解決策として, サンプル輪郭モデル (4) を利用 した手法などが提案されているが, Snakes と同じ初期座標 設定問題が完全には解決されていない。また, 現実の画像 処理問題においては, 例えば面積のような要素をもつ対象 を捕捉するには 1 次元的な輪郭上の情報だけでは不充分な ことが多い。

これらの問題に対して，坂上らが提案した領域抽出に関す る手法として動的なネットモデル (1) がある。これは, Snakes を 2 次元に拡張した変形可能なモデルである。Active Net の特徵は，そのモデル内部にも画像情報を取り込むことが できる能力を持っているため, 輪郭だけに注目する Snakes と異なり, 対象領域内部の情報 (テクスチャ情報など)を 考慮した対象検出が可能となることである。したがって, Snakes よりも安定した形状抽出が可能である。 
従来から用いられている Active Net の構造には，正方 格子, 同心四角ネット，同心円ネットなどがある(1), (5)。そ して, 正方格子, 同心四角ネットにおいては, 初期のネッ トをほぼ画像全体を覆うように設定することができ，画像 の端にある対象領域を捕捉することが可能である。しかし， 対象の大きさによっては，捕捉できない場合がある。また， 一つのネットで一つの画像全体に対して一対象しか捕捉す ることはできない。そこで, われわれは, 等面積構造を持つ ネット構造を提案した ${ }^{(5)}$ 。これにより, 画像の中心から離 れた対象の捕捉が可能となったが，一つのネットで一つの 対象しか捕捉できていない。その問題に対しては, snakes に関連して提案された分離方法 ${ }^{(6)}$ を Active Net に適用し, 複数の対象を一つのネットで捕捉した後, ネットを分離し, 個々の対象を捕捉する方法が考えられる。しかし，この方 法に打いては，一つの対象を捕捉するための処理時間がか かる上，分離のためにより多くの計算時間が必要であるこ とは明らかである。さらに，分離する方法は，高速計算の ための並列化には向いていない。また，複数の Active Net 間で協調動作をする方法が提案されている(7)。これは，各 対象の特定の位置関係が分かっている顔の各部の検出にお いて利用されており，位置関係が定義しにくい場合におい てはネット間の協調動作は困難となり，さらに，個々の対 象が独立している場合には協調動作は不要である。

一方，動的輪郭モデルのもう一つの方法として Level Set Method $^{\left({ }^{(8)}\right.}$ が提案されている。この方法は, 対象の数や包 含関係といった位相の変化にも対応できる。例えば，動画 像に抢ける複数の動物体の追跡に用いる場合，離れている 動物体はそれぞれの輪郭が検出でき，その後重なった状態 でも一つの輪郭となって重なった領域を検出することがで きる。しかし，画像全体に対して処理が行われるなどのた め，計算コストがかかる。Active Net と比較すると，対象 の内部情報を利用できないこと，このままでは並列化には 向いていない問題点がある。

そこで，本稿に执いては，今後進んでいくであろう，並 列処理を考慮すべく, 複数のターゲットに対して, 複数ア クティブネットを適用する方法を提案する。すなわち，同 時に多くの対象を捕捉できるよう，また，画像の端にある 対象を捕捉できるよう，画像を見掛け上分割してネットを 各分割領域に適用する方法を提案し，本方法について基礎 的な検討を行う ${ }^{(9)}$ 。ここで，本論文においては，個々の対 象は㧍互いの位置関係はなく独立している場合，例えば道 路情景画像から道路標識を検出するような場合，を想定し ているため協調動作を行う必要はなく，そのため各ネット の計算時間を短く処理することができる特徵を持っている といえる。

以下では，まず， 2 章で Active Net の原理について述 べ, 3 章で従来法での問題点について整理し，4 章で画像 を見掛け上分割した各分割領域に Active Net を適用する マルチネット方式について提案し，シミュレーション実験 および実画像への適用実験の結果について述べる。

\section{Active Net}

Active Netはエネルギー最小化原理に基づいた動的な ネットモデルである。すなわち, 網に対して定義されたエ ネルギーが極小状態になるように自ら変形を繰り返しなが ら領域を抽出する。網の全体像は Fig. 1 に示したように, その構造は, 格子点 $\mathbf{v}(p, q)=(x(p, q), y(p, q)), 0 \leq p \leq 1$, $0 \leq q \leq 1$ の集まりからなり, 各格子点は隣り合う 4 近傍 の点 $\mathbf{v}(p, q-l), \mathbf{v}(p-k, q), \mathbf{v}(p+k, q), \mathbf{v}(p, q+l)$ と結合さ れて網を形成している (Fig. 2)。ここで，x，yはそれぞれ 画像の水平，垂直方向の座標を表していとすると $k=1 /(\mathrm{x}$ 方向の格子点数 $), l=1 /(\mathrm{y}$ 方向の格子点数) である。

このアルゴリズムでは，ネットモデルに対して，網の内 部歪みエネルギー $E_{i n t}$ 抢よび網と画像の適合性エネルギー $E_{\text {image }}$ の 2 つのエネルギーが与えられており, 網のエネ ルギー汎関数 $E_{n e t}$ はこれらの和として次式で定義されて いる。

$$
\begin{aligned}
E_{\text {net }}= & \int_{0}^{1} \int_{0}^{1}\left\{E_{\text {int }}(\mathbf{v}(p, q))\right. \\
& \left.+E_{\text {image }}(\mathbf{v}(p, q))\right\} d p d q .
\end{aligned}
$$

内部歪みエネルギー $E_{i n t}$ は網を収縮させかつその形状 を滑らかに保とうとするエネルギーに対応しており，一般 的に以下のように記述される。

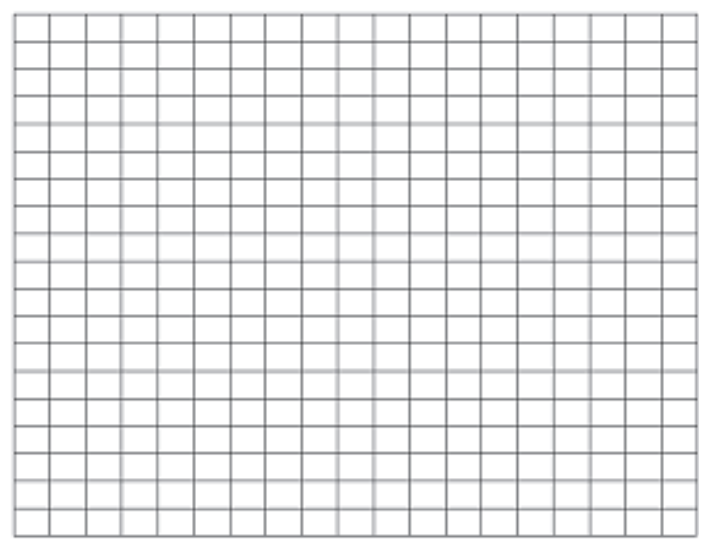

Fig. 1. The lattice net.

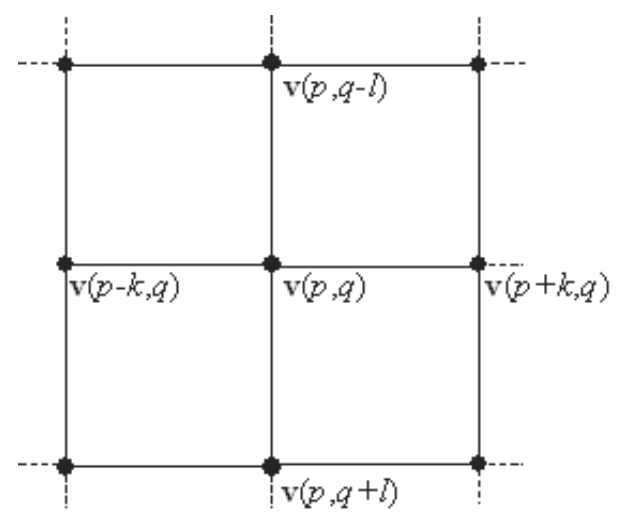

Fig. 2. The lattice point structure of Active Net. 


$$
\begin{aligned}
E_{\text {int }}=\{ & \alpha\left(\left|\mathbf{v}_{p}\right|^{2}+\left|\mathbf{v}_{q}\right|^{2}\right) \\
& \left.+\beta\left(\left|\mathbf{v}_{p p}\right|^{2}+2\left|\mathbf{v}_{p q}\right|^{2}+\left|\mathbf{v}_{q q}\right|^{2}\right)\right\} / 2 \cdots
\end{aligned}
$$

ここで，添字は偏微分を表し， $\alpha$ と $\beta$ は重み係数である。 この式は 2 つの項から定義されており，第 1 項目は網を収 縮する力, 第 2 項目は網の滑らかさを保つ力をそれぞれ表 している。画像の適合性エネルギー $E_{\text {image }}$ は画像内の特 徵的 (濃淡レベル, 画像の滑らかさなど) な領域へ網を導く 力に対応している。すなわち, Active Net は対象物体の特 徵 (濃淡レベルなど) を表す $E_{\text {image }}$ を定義すると, 網自身 をその対象に引き寄せる力が生じる。 $E_{\text {image }}$ の最も単純な ものとしては,

$$
E_{\text {image }}=w I(x, y)
$$

である。ここで, $I(x, y)$ は格子点 $\mathbf{v}(=(x, y))$ での濃淡レ ベルを表している。 $w$ は係数であり, $w>0$ とした場合, 網 は濃淡レベルの低い方へと引きつけられるようになる。一 般的に $E_{\text {image }}$ は, Active Netの輪郭上の格子点が対象物 の外側にあり内部の格子点が対象物領域内にある場合，小 さな值をとるように定義される。本稿では，(3) 式の定義 を使用している。(1) 式の最小化は沉関数に㧍ける極值問 題であり, 変分法の枠組みであるオイラー・ラグランジュ の方程式によって解くことができる。これにより以下の独 立な 2 つの式を得る。

$$
\begin{array}{r}
-\alpha\left(x_{p p}+x_{q q}\right)+\beta\left(x_{p p p p}+2 x_{p p q q}+x_{q q q q}\right) \\
+\frac{\partial E_{\text {image }}}{\partial x}=0 \ldots \ldots \ldots \ldots \ldots \ldots \ldots \ldots \ldots \ldots \ldots \ldots \ldots \ldots \ldots \ldots \ldots \\
-\alpha\left(y_{p p}+y_{q q}\right)+\beta\left(y_{p p p p}+2 y_{p p q q}+y_{q q q q}\right) \\
+\frac{\partial E_{\text {image }}}{\partial y}=0 \ldots \ldots \ldots \ldots \ldots \ldots \ldots \ldots
\end{array}
$$

これら偏微分方程式の各項を差分近似式に置き換えるこ とにより，格子点の $\mathrm{x}$ 座標㧍よび $\mathrm{y}$ 座標についての連立方 程式ができる。それらの式は，初期網の位置を初期值とし てヤコビ法に基づく並列型反復法を用いて解かれる。すな わち, Active Net の振舞いとは, 反復演算中に逐次求まる 近似解に対応しており, 網はダイナミックに変形しながら

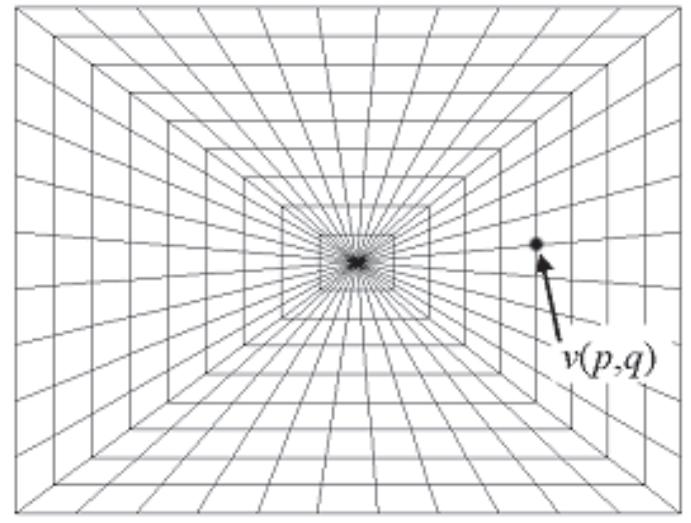

Fig. 3. The square net with a center.
最終解 (エネルギー極小解) に落ち着く。本稿では, この格 子ネットから同心型に変更した，中心を持った四角形構造 の同心四角ネットを用いる。Fig. 3 に同心四角ネットの初 期形状を示す。

以下で示す本稿の実験において，ネットの収束の最終結 果の条件としては，特別に条件は設定せず，ネットの各格 子点座標が変化しなくなったところ（エネルギーが極小と なった時点）としている(10)。

\section{3. 従来法における問題点}

Fig. 4 の対象 1 個の入力画像に対して, 従来の同心四角 ネットを適用するシミュレーションを行う。そのシミュレー ション結果を Fig. 5，6 に示す。Fig. 5 では四角形の対象画 像と同心四角ネットで反復演算を 1 回行っている。Fig. 6 は処理結果である。この場合, 対象領域は画像の端にあっ て, 初期ネットは対象領域を覆っているが, Fig. 6 に示さ れるように対象は捕捉できていない。この理由は, (1)〜 (3) 式に扔いて，対象とネットの関係で決まるエネルギー $E_{i n t}$ と $E_{\text {image }}$ によるネットの収縮力とネットを対象に引き寄 せる力の大小により捕捉の可否が決り, この実験の場合は, ネットを対象に引き寄せる力よりも収縮力が勝っていたた め，捕捉できなかったと考えられる。また，対象が $1 つ に$ 対してネットが 1 つか利用できないので, 対象が 1 つで ない場合には同じ動作を繰り返す必要がある。そこで，こ

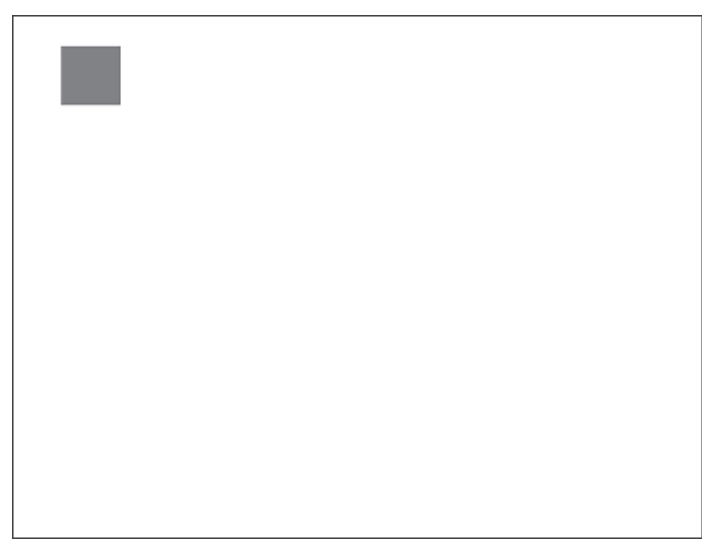

Fig. 4. An input image.

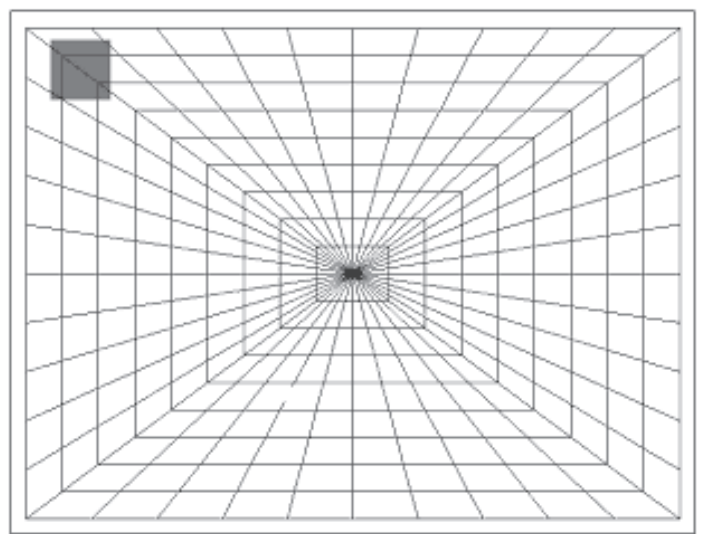

Fig. 5. Initial shape of conventional net. 


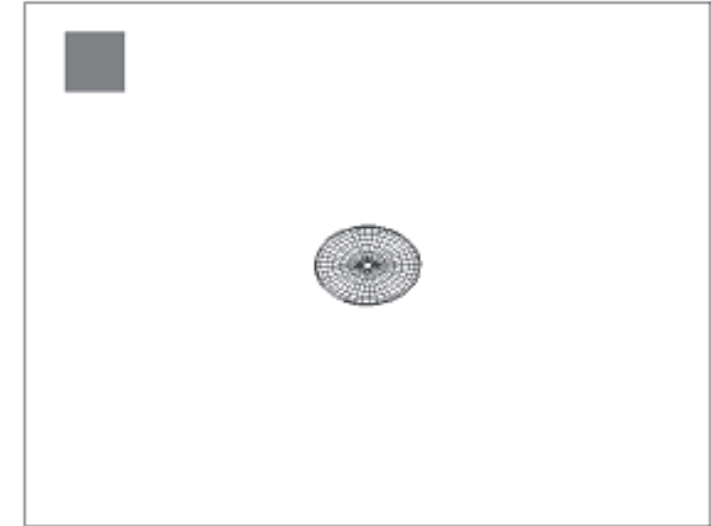

Fig. 6. Final simulation result using conventional net.

の問題点を改善するため, 画像をいくつかに分割したとし て, Active Netを適用する方法を提案する。以下では, こ の方式をマルチネット方式とよび，次章で，4 面分割方式 と 9 面分割方式について示す。な扔，本稿に扔いては，画 像に存在する対象は，分割領域に適応したネットで覆うこ とができる大きさで，同じような大きさのものが複数個あ り，位置は未知と想定している。

\section{4. マルチネット方式の提案}

この章では，提案するマルチネット方式について説明を 行う。たとえば，画像を $\mathrm{n}$ 個の領域に分割し，それぞれの 領域をカバーできるサイズのネットを $\mathrm{n}$ 個の各領域に適用 する。たとえば, $\mathrm{n}=4$ とした場合は Fig. 7 である。以下， $\mathrm{n}=4,9$ とした場合の 4 面分割方式及び 9 面分割方式のシ ミュレーション結果を用いて本手法の効果を検討する。な 㧍，本方式では， $\mathrm{n}$ の值を変更することにより，分割数を 増やすことも減らすことも可能となる。

$\langle\mathbf{4} \cdot \mathbf{1}\rangle \quad 4$ 面分割方式 Fig. 8 に示方対象画像は Fig. 4 に対象を一つ加えたものである。Fig. 8 に 4 面分割方式を 適用するシミュレーション実験を行う。入力画像とネット の初期形状を Fig. 9 とし，この結果を Fig. 10，11 に示す。 Fig. 10 は反復 1000 回目の状態を示している。Fig. 11 の 左上のネットは反復 2218 回, 左下のネットは反復 4472 回 の結果である。このように Fig. 6 で捕捉できていない $1 つ$ の対象は，きれいに捕捉されていることが分かる。しかし， 中央にある対象は，捕捉できなかった。この理由は, Fig. 9 に打いて, 中央の対象が左下のネットからはみ出し, また, そのネットの最外郭の格子点が対象の周囲に存在しないこ とによるためである。これにより、ネットの初期形状にお いて対象がそのネットに覆われている必要があることが分 かる。

$\langle\mathbf{4} \cdot \mathbf{2}\rangle \quad 9$ 面分割方式 4 面分割方式の発展系である 9 面分割方式について検討してみる。これは，対象の存在座標 が問題で，4面分割方式で捕らえられなくなった領域（ネッ 卜間の中心部分）を補うために，4つのネットの間を中心と したネットをさらに追加したものである。Fig. 12 にネット

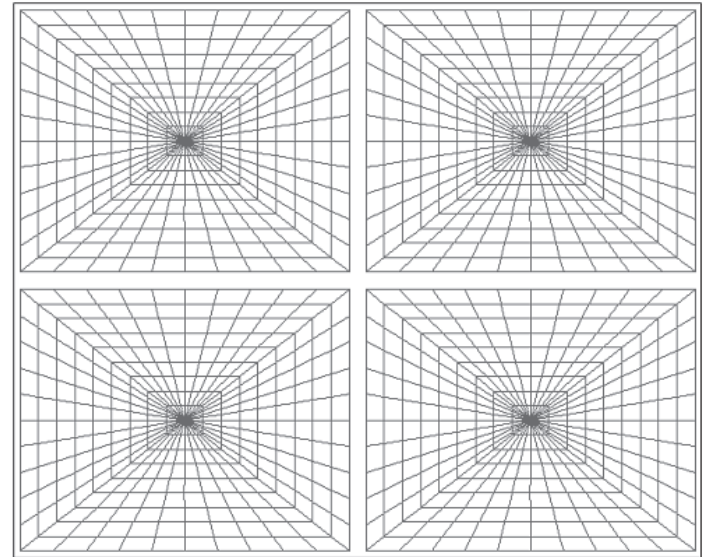

Fig. 7. Proposed $\operatorname{method}(\mathrm{n}=4)$.

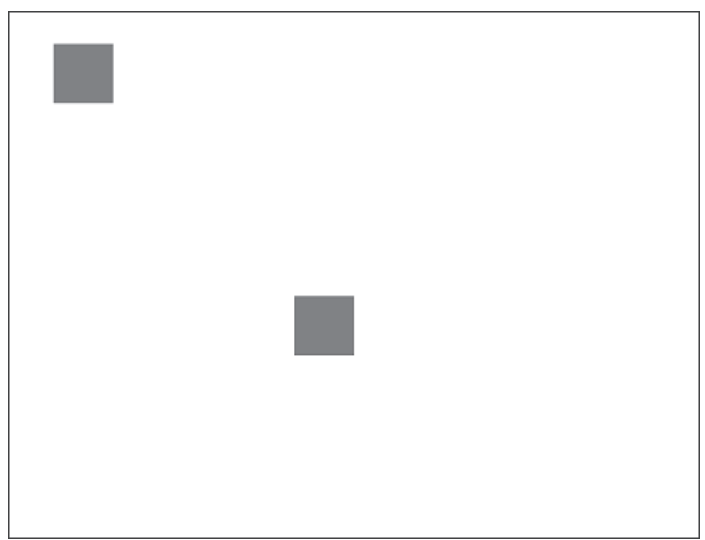

Fig. 8. Two target image.
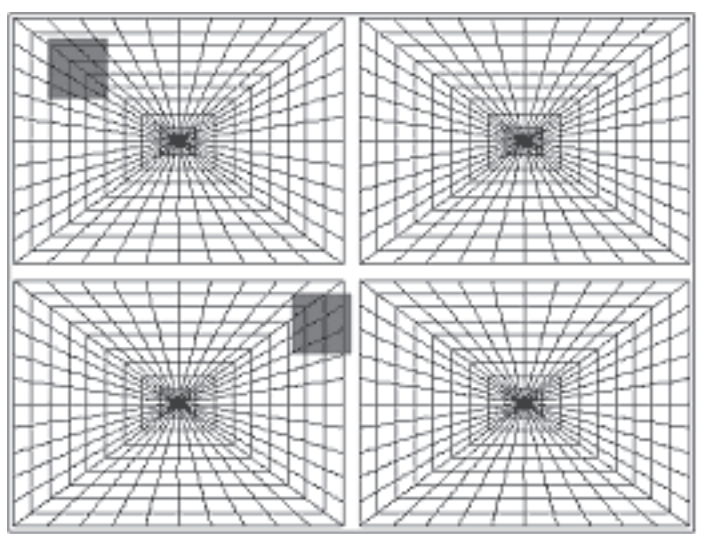

Fig. 9. Initial shape of a net of proposed $\operatorname{method}($ the number of nets:n=4).

の配置と Fig. 13，14，15 にシミュレーション結果を示す。 Fig. 13 は反復 100 回目の状態を示している。Fig. 14 は反 復 1000 回目の状態を示している。Fig. 15 に扔いてエネル ギーの変化がなくなったことにより，2つの対象を捕捉し ていることが分かる。ここで, 左端の対象は左上のネット (反復 2218 回), 中央の対象は, 中央 (反復 1020 回), 中 央下（反復 1667 回）の 2 つのネットにより捕捉されてい る。左中（反復 4571 回）, 左下（反復 4472 回）のネット は中央の対象に一部かかっているのみで，対象を覆うよう 


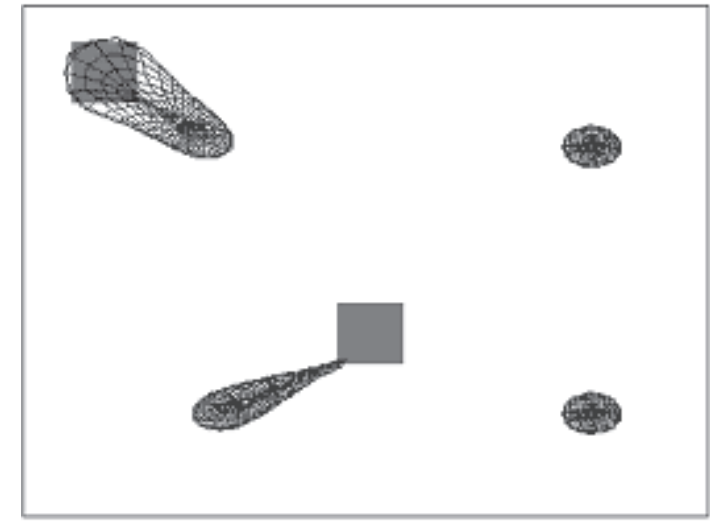

Fig. 10. Simulation result, $\mathrm{n}=4$ (the number of iteration is 1000).

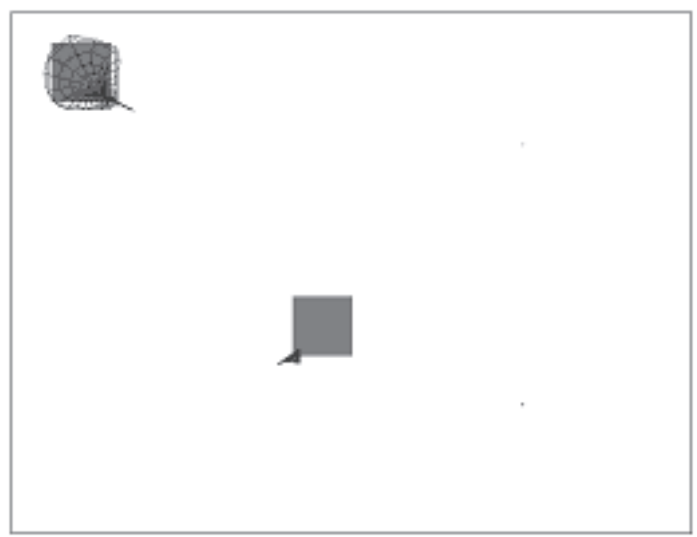

Fig. 11. Final simulation result with using proposed method, $\mathrm{n}=4$.

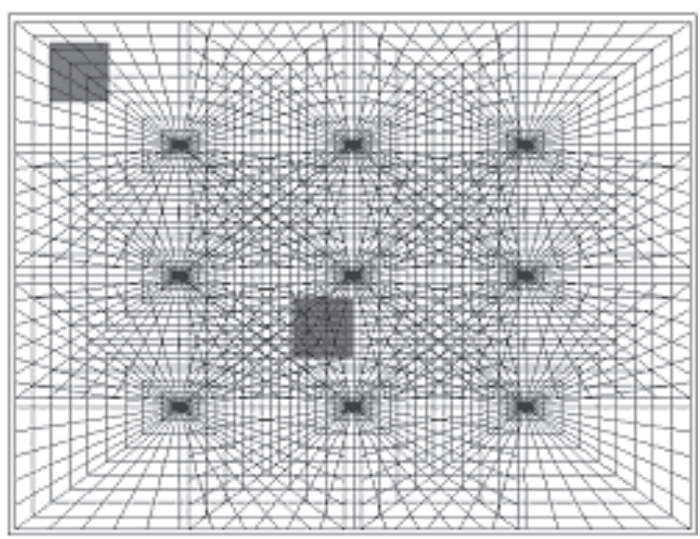

Fig. 12. Initial shape of a net of proposed method(the number of nets: $n=9$ ).

にかかっていないので捕捉はできていない。その他のネッ トについては，各ネットの中心部へ収束しており，Fig. 15 でははっきりと見えないが小さな点で示されている。

〈4·3〉 実画像への適用一例として, 4 面分割方式を Fig. 16 に示す実画像に適用する。この画像は，ディジ夕 ルカメラで撮影した道路標識が存在する道路情景画像から, 予め赤色分布にあわせて作成しておいた色分布関数 (11) を 用いて，赤色領域を抽出した画像（類似度マップと呼んで

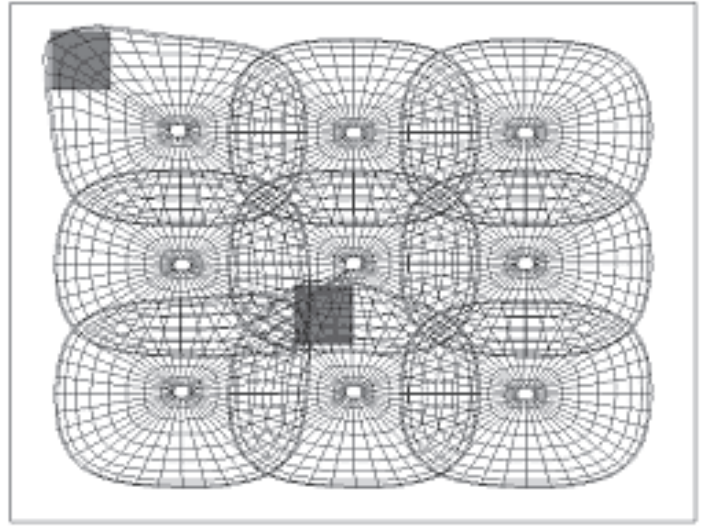

Fig. 13. Simulation result, $\mathrm{n}=9$ (the number of iteration is 100).

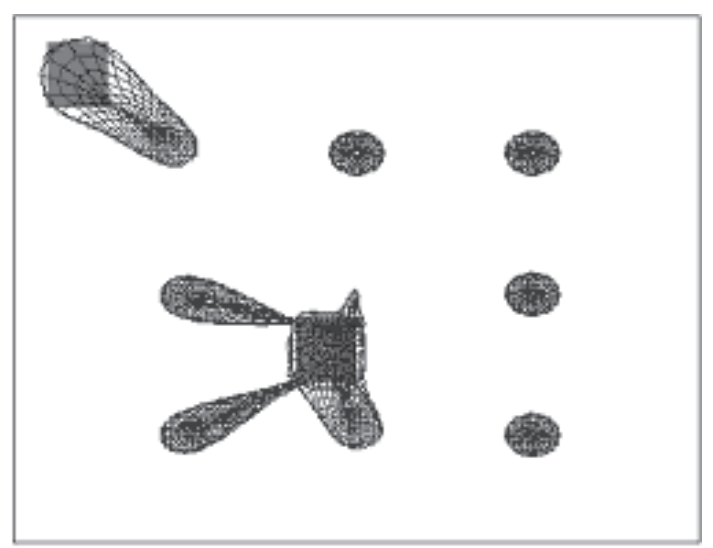

Fig. 14. Simulation result, $\mathrm{n}=9$ (the number of iteration is 1000).

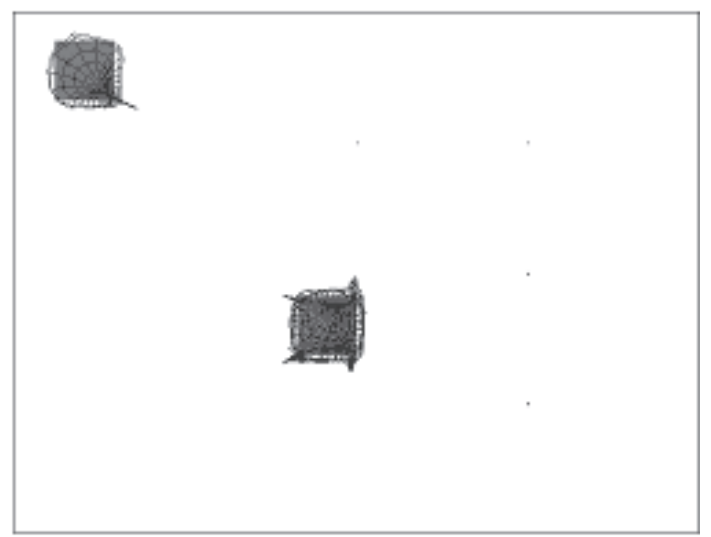

Fig. 15. Final simulation result with using proposed method, $n=9$.

いる）である。抽出対象は，黒い領域であり，1つは画像 のほぼ中央にある速度標識の赤色部分に該当するリング形 状のもので，もう1つは画像の左下にある標識ではない赤 色領域である。ネットの初期状態を表したものが，Fig. 17 である。実験結果を Fig. 18，19 に示す。Fig. 18 は反復 500 回後の結果であり, Fig. 19 は反復 4500 回後の結果で ある。リング形状の領域は完全に捕捉されているが, 左下 の領域は, 左側が薄くなっているため右側部分を捕捉して 


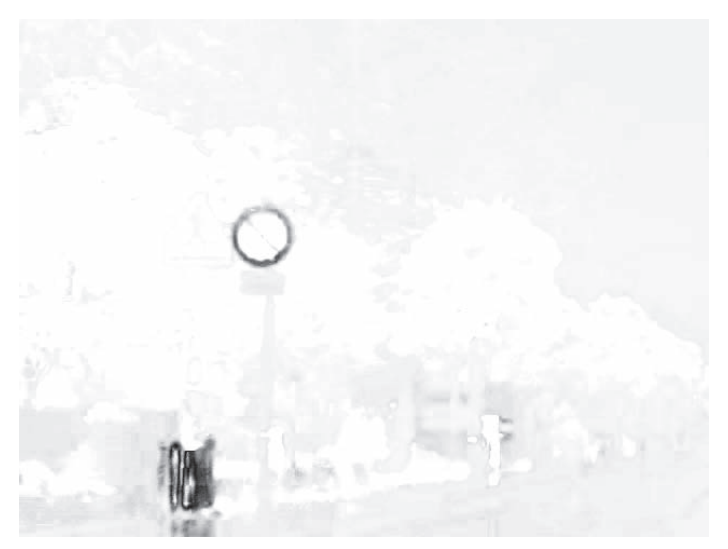

Fig. 16. Real image.

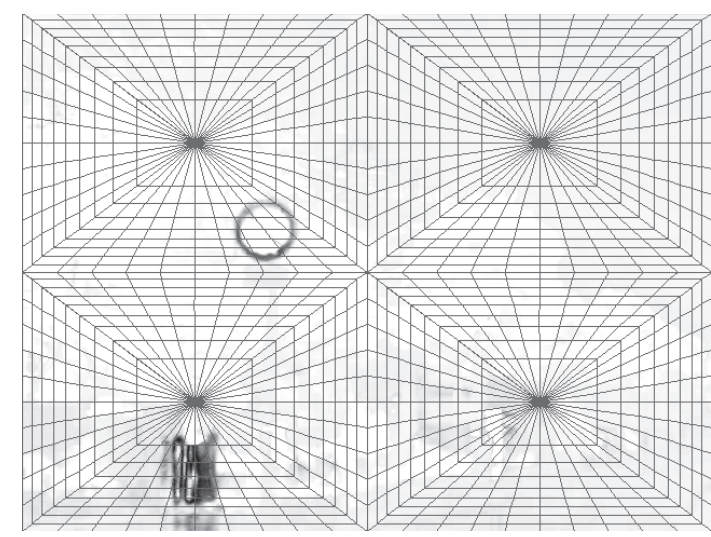

Fig. 17. Initial shape of a net, $\mathrm{n}=4$.

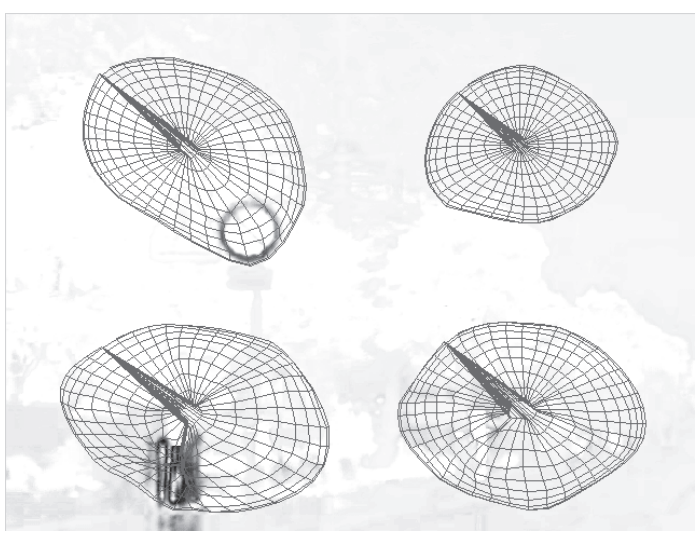

Fig. 18. Experimental result, $\mathrm{n}=4$ (the number of iteration is 500).

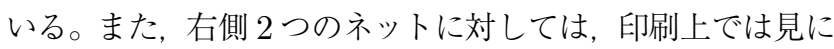
くいが, 薄い背景としての領域が表れており，その影響に よりエネルギーの極小状態となり収束がほほ停止したもの となっている。これより，4分割方式のネットは，正しく動 作していることが分かる。な拉，左下のネットの捕捉結果 においては，1領域において濃度值が大きく異なる領域があ る場合は，濃度值の大きい領域のほうに偏るという動的な ネットモデルの性質があるため, 本論文のマルチネットと いう目的に対して，ある程度の濃度差がある場合には，こ の程度の濃度差は捕捉に対して明確に区別可能であり，問

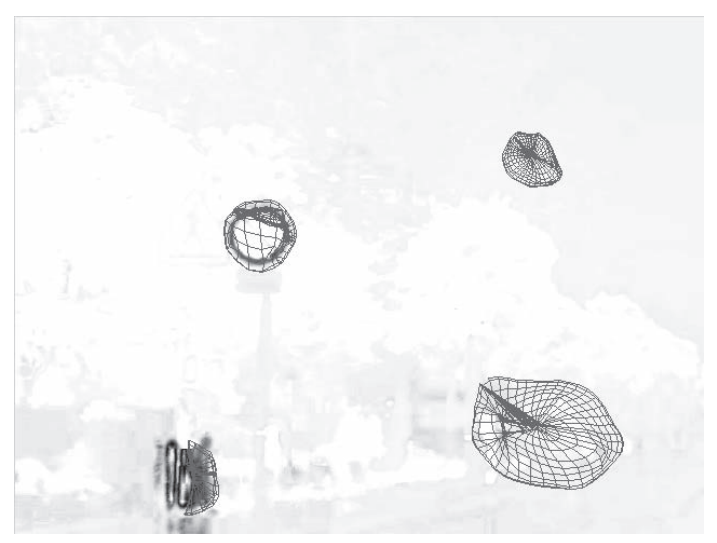

Fig. 19. Experimental result, $n=4$ (the number of iteration is 4500).

題ない範囲と考えられる。実際にアプリケーションに適用 する場合は，濃度值の低い領域はあらかじめ削除しておく ことにより, Fig. 19 の右側の 2 つのネットのように対象以 外を捕捉することはなくすことが可能と思われる。

$\langle 4 \cdot 4\rangle 4$ 面分割方式と 9 面分割方式の適用実験結果に よる検討 Fig. 10 の 4 面分割方式で捕捉できなかった 対象は Fig. 12〜 15の 9 面分割方式では, 結果に示すとお り対象を捕捉することができた。また，実画像に適用した 結果に扔いて, 右側 2 つのネットに対しては, 薄い背景と しての領域が表れネットの収束が停止し, 捕捉が完了して おり，さらにはっきりと確認できる左側の 2 つの対象を捕 捉することができている。印刷上ははっきりしていないが, 画面上では薄く見にくいようなものであっても，濃度差が あるものに対しては捕捉するかしないかは明確に区別可能 である。現時点では，これらの処理は，逐次計算を行って いるので，ネット数が増えれば増えるだけ，処理時間がか かってくる。しかし，将来的には，ネット間での並列処理 を考えており，時間的には問題はなくなってくると考えら れる。

また, Active Netの問題である一つのネットで一つの対 象しか捕捉できない性質を積極的に利用し，4 面分割方式 と 9 面分割方式のように見掛け上画像を分割した分割領域 に適用されたネットにより, 画像中のすべての対象に対し て捕捉が可能であることがシミュレーションにより示すこ とができた。ネット 1 つについての計算時間については, 従来の方法に比べて, 対象領域のサイズが小さくなったた め短い時間で対象を捕捉することが可能となっている。さ らに，小さいネットでは格子点間の距離が短くなっている ため，すなわち，ネットを対象に引き寄せる力が大きくな り，画像の端にある対象も捕捉でき，対象の捕捉能力は向 上できることになる。

ところで，分割方式を適用するときに使用するネットよ り，対象が大きい場合も考えられる。大きい対象のみにお いては，提案した分割方式とともに従来の大きいネットを 併用することで，対象を捕捉することはできる。しかし，大 
きい対象と小さい対象が存在する場合については，従来の 大きいネットと提案した分割方式のネットがそれぞれどの ように対象を捕捉するかについては今後の検討課題である。 さらに，適用するアプリケーションにおいて，1画像中 に存在すると思われる対象の大きさは想定されるので，対 象の数や位置が未知でも自動的に分離する方法やより小さ く分割することによる繰り返し処理により対応することは 可能であると思われる。

\section{5. むすび}

本稿では，画像中の対象を捕捉する方法として，新たに マルチネット方式を提案し，4 面分割方式と 9 面分割方式 を用いて, シミュレーション実験拉よび実画像への適用実 験を行った。これより，従来の方法では，捕捉できなかっ た対象が捕捉できるようになり，基礎的な部分に招いて本 方式の有効性を示すことができた。本手法では，個々の対 象は㧍互いの位置関係はなく独立しているような場合にお いて協調動作を行う必要はなく，そのため各ネットの計算 時間を短く処理することができる特徵を持っていることを 示すことができた。

今後においては，本稿で提案した方法の応用面の検討や 並列処理を含めた演算時間の短縮を検討することなどが上 げられる。また，大きい対象と小さい対象が存在する場合， さらに，小さい対象が大きな凹に小さな対象が嵌り込んで いる場合に拉いて，従来の大きいネットと提案した分割方 式のネットがそれぞれどのように対象を捕捉するかについ ては今後の検討課題である。

(平成 19 年 11 月 20 日受付, 平成 20 年 12 月 3 日再受付)

\section{文献}

(1) K. Sakaue and K. Yamamoto: "Active Net Model and Its Application to Region Extraction", J. ITE Japan, Vol.45, No.10, pp.1155-1163 (1991-10) (in Japanese)

坂上勝彦・山本和彦：「動的な網のモデル Active Net とその領域抽 出への応用」, テレビ誌, 45, 10, pp.1155-1963 (1991-10)

(2) N. Yokoya and K. Sakaue: "Image Understanding and Optimization Principles", J. IEICE Japan, Vol.74, No.4, pp.326334 (1991-4) (in Japanese)

横矢直和 - 坂上勝彦：「画像理解と最適化原理」, 信学会, 74,4 , pp.326-334 (1991-4)

(3) M. Kass, A. Witkin, and D. Terzopoulos: "Snakes: active contour models", IJCV, Vol.1, No.4, pp.321-331 (1988)

(4) A. Amano, Y. Sakaguchi, M. Minoh, and K. Ikeda: "Snakes Using a Sample Contour Model", Trans. IEICE Japan, Vol.J76-D-II, No.6, pp.1168-1176 (1993-6) (in Japanese) 天野 晃・坂口嘉之・美濃導彦・池田克夫:「サンプル輪郭モデルを利 用したSnakes」, 信学論, J76-D-II, 6, pp.1168-1176 (1993-6)

(5) N. Yabuki, Y. Matsuda, M. Ota, Y. Sumi, Y. Fukui, and S. Miki: "Improvement of Active Net model for region detection in an image", IEICE Trans. Fundamentals, Vol.E84-A, No.3, pp.720-726 (2001-3)

(6) B. Vemuri, Y. Guo, and Z. Wang: "Deformable Pedal Curves and Surfaces, Hybrid Geometric Active Models for Shape Recovery", Invernational Journal of Computer Vision, Vol.44, No.2, pp.137-155 (2001)

(7) R. Funayama, N. Yokoya, H. Iwasa, and H. Takemura: "Cooperative Active Net Models and Its Application to $\mathrm{Fa}-$ cial Component Extraction", Tech. Report of IEICE Japan,

Vol.PRU95-179, pp.15-22 (1995-12) (in Japanese)

船山竜士・横矢直和・岩佐英彦・竹村治雄 :「複数の動的な網のモデ ルの協調とその顔部品抽出への応用」，信学会技研報, PRU95-179, pp.15-22 (1995-12)

(8) S. Osher and J. A. Sethian: "Fronts propagating with curvature dependent speed: Algorithm based on HamiltonJacobi formation", Journal of Computational Physics, Vol.79, pp.12-49 (1988)

(9) T. Noda, N. Yabuki, Y. Sumi, S. Matsumae, Y. Fukumoto, T. Ueta, and Y. Fukui: "A study of active net model by multiple methods", The 17th Workshop on Circuits and Systems in Karuizawa, pp.171-175 (2004-4) (in Japanese) 野田尚志·薮木 登・熟見育亮・松前 進·福本善洋・植田拓也·副 井 裕:「動的なネットモデルのマルチ方式化に関する検討」, 第 17 回 回路とシステム軽井沢ワークショップ, pp.171-175 (2004-4)

10) N. Yabuki, Y. Matsuda, D. Kataoka, Y. Sumi, Y. Fukui, and S. Miki: "A Study on an Automatic Stop of Computation in Active Net", Tech. Report of IEICE Japan, Vol.PRU99-213, pp.69-76 (2001-1) (in Japanese)

薮木 登・松田喜貴・片岡 大・熟見育亮・副井 裕·三木成彦： 「動的なネットモデルの演算自動停止に関する一考察」，信学会技研 報, PRMU99-213, pp.69-76 (2001-1)

11) N. Yabuki, Y. Matsuda, H. kimura, Y. Fukui, and S. Miki: "Region Extraction Using Color Feature and Active Net Model in Color Image", IEICE Trans. Fundamentals, Vol.E82-A, No.3, pp.466-472 (1999-3)

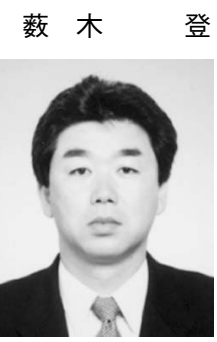

登（非会員） 1985 年鳥取大学工学部電気工学科卒 業。1987 年同大学院修士課程修了。同年津山工 業高等専門学校電気工学科助手, 1988 年同情報 工学科助手, 1999 年同講師, 2001 年同助教授, 2007 年同准教授， 2008 年同教授，現在に至る。 画像処理, 画像認識の研究に従事。博士 (工学)。 電子情報通信学会, 映像情報メデイア学会各会員。

熟 見育亮

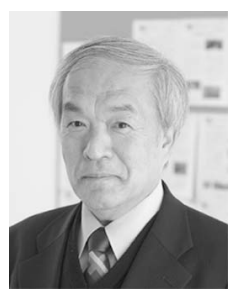

難 波 福 弥

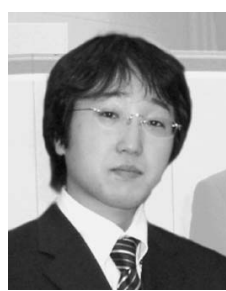

築 谷 隆 雄

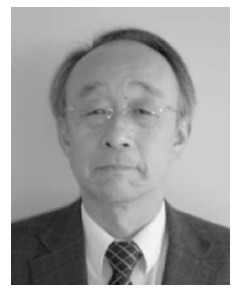

(非会員) 1969 年鳥取大学工学部電気工学科卒 業。同年鳥取三洋電機（株）入社。1998 年鳥取 大学院博士課程修了。2001 年鳥取環境大学情報 システム学科教授，現在に至る。電子回路，画像 処理，画像認識の研究に従事。博士 (工学)。電 子情報通信学会, IEEE 各会員。

（非会員） 2007 年鳥取環境大学情報システム学 科卒業。同年鳥取環境大学大学院修士課程入学, 現在に至る。画像処理，画像認識に興味を持つ。 電子情報通信学会会員。

（正員） 1974 年鳥取大学工学部電気工学科卒業。 同年松江工業高等専門学校電気工学科助手, 1981 年同講師, 1988 年同助教授, 1998 年同教授, 現 在に至る。電子回路, 信号処理の研究に従事。博 士 (工学)。電子情報通信学会会員。 